\title{
TRANSAKSI JUAL BELI DENGAN SISTEM MEMBER CARD DALAM PERSPEKTIF EKONOMI ISLAM \\ (Penelitian Pada Toko Sophie Paris Hibrida Bengkulu)
}

\author{
Istikomah $^{1}$ dan Dira Rahmayeti $^{2}$ \\ MI Muhajirin ${ }^{1}$ dan Divisi Marketing CV. Sinar Abadi ${ }^{2}$ \\ istieimoet@rocketmail.com
}

\begin{abstract}
The purpose of this study was to determine the legal system of member cards in buying and selling transactions in Sophie Paris Hybrid city of Bengkulu in the perspective of Islamic economics. This study used descriptive qualitative method. Data collection techniques carried out by observation, interviews and documentation. The research informants were determined by purposive sampling, namely the Business Center owner, Business Center assistant and member card user members. Data analysis was performed using data reduction techniques, data presentation and conclusion drawing. The results of this study conclude that: The member card system in buying and selling transactions at Sophie Paris who want to join as a member member pays Rp.70,000 registration fee, gets a bag, guidebook, and ID card, 30\% discount on Sophie Paris catalog 20\% Sunday catalog, bonuses and rewards for each rank up. The member card system in buying and selling transactions in the perspective of Islamic economics that is given free or paid at the beginning of registration is legitimate and permissible, if not contrary to Islamic economic principles. From the explanation of the fatwa institutions it can be understood that the member card system is not allowed to collect money for take advantage of consumers who want to become members, but the collection of money is permitted if the money withdrawn from the member card holder is only limited to the cost of making the card and the issuer does not take advantage of the card issuance at all. The member card system at Sophie Paris Hybrid with a paid system at the beginning of the registration must not be because the registration or administration money is not a substitute for making member card financing but registration money if you want to join as a member member.
\end{abstract}

Keywords: System, Member Card, Buy and Sell in Islam.

\begin{abstract}
Abstrak. Tujuan penelitian ini adalah untuk mengetahui hukum sistem member card dalam transaksi jual beli di Sophie Paris Hibrida kota Bengkulu perspektif ekonomi Islam. Penelitian ini menggunakan metode deskriptif kualitatif. Teknik pengumpulan data dilakukan dengan observasi, wawancara dan dokumentasi. Informan penelitian ditentukan secara purposive sampling yaitu pemilik Business centre, asistenBusiness centre dan anggota penguna
\end{abstract}


member card. Analisis data dilakukan dengan teknik reduksi data, penyajian data dan penarikan kesimpulan. Hasil penelitian ini menyimpulkan bahwa: Sistem member card dalam transaksi jual beli di Sophie Paris yang ingin bergabung menjadi anggota member membayar uang pendaftaran Rp.70.000, mendapatkan tas, buku panduan, dan ID card, diskon 30\% katalog Sophie Paris 20\% katalog Sunday, bonus dan reward setiap naik peringkat. Sistem member card dalam transaksi jual beli perspektif ekonomi Islam yang diberikan secara cuma-cuma ataupun berbayar pada awal pendaftaran sah dan boleh saja, jika tidak bertentangan dengan prinsip ekonomi Syariah.Dari penjelasan lembaga-lembaga fatwa dapat dipahami bahwa sistem member cardtidak dibolehkan memungut uang untuk mengambil keuntungan lebih dari konsumen yang ingin menjadi anggota, namun pemungutan uang tersebut diperbolehkan jika uang yang ditarik dari pemegang member card hanya sebatas uang pengganti biaya pembuatan kartu dan pihak penerbit sama sekali tidak mengambil keuntungan dari penerbitan kartu tersebut. Sistem Member card di Sophie Paris Hibrida dengan sistem berbayar pada awal pandaftaran itu tidak boleh karena uang pendaftaran atau administrasi bukan sebagai pengganti pembiayaan pembuatan member card melainkan uang pendaftaran jika ingin bergabung menjadi anggota member.

Kata Kunci: Sistem, Member Card, Jual Beli Dalam Islam.

\section{Pendahuluan}

Ekonomi sebagai suatu usaha mempergunakan sumber-sumber alam secara rasional untuk memenuhi kebutuhan-kebutuhan, sesungguhnya melekat pada watak manusia.Tanpa disadari, kehidupan manusia sehari-hari didominasi kegiatan ekonomi. Sebutan secara rasional pada dirinya mengandung arti nilai, mempergunakan sumbersumber daya secara rasional menunjukkan adanya keharusan memilih sejumlah alternatif cara penggunaan sumber-sumber daya, akan tetapi secara ekonomi cara yang lebih rasionalah yang seharusnya dipilih. rasionalitas disini telah mennyiratkan nilai ekonomi.

Di era globalisasi dan perdagangan bebas ini, dengan dukungan ilmu pengetahuan, teknologi, dan informasi yang mudah didapat maka semakain luas alur keluar masuknya barang dan jasa melintasi batas-batas Negara, hal ini mempermudah masyarakat untuk memenuhi kebutuhan akan barang dan jasa. Perkembangan teknologi dan ekonomi yang sangat pesat telah menghasilkan berbagai jenis dan variasi dari masing-masing barang dan jasa yang dapat dikonsumsi. Barang dan jasa tersebut pada umumnya merupakan barang dan jasa yang beraneka ragam. Dengan digolongkan produk yang sedemikian banyaknya melalui dukungan

${ }^{1}$ Abdul Aziz, Mariyah Ulfah, Kapita Seleka Ekonomi Islam Kontemporer (Cirebon: Alfabeta, 2010), h. 48 
teknologi komunikasi dan informasi, maka telah terjadi perluasan ruang gerak arus transaksi barang dan jasa yang melintas batas-batas wilayah suatu negara baik yang berasal dari dalam negeri maupun di luar negeri. ${ }^{2}$

Bisnis merupakan aktivitas manusia secara keseluruhan dalam upaya mempertahankan hidup, mencarai rasa aman, memenuhi kebutuhan, sosial dan harga diri serta mengupayakan pemenuhan aktualisasi diri, yang pada kesemuanya secara intern terhadap nilai-nilai etika. Etika dibutuhkan dalam bisnis ketika manusia mulai menyadari bahwa dibidang bisnis justru telah menyebabkan manusia semakin tersisih dari nilai-nilai kemanusiaan dan mendorong munculnya egoisme dan praktek monopoli, sifat ingin menguasai apa saja tanpa pernah merasa puas. Manusia takut persaingan bisnis menjadi tidak sehat dan tidak lagi memperhatikan norma dan etika. ${ }^{3}$

Pelanggaran nilai etika dalam bisnis atau dalam perdagangan mungkin atau tidak mungkin akan menimbulkan kerugian seketika atau kerugian yang dapat dilihat oleh pihak-pihak yang melakukannya. Tetapi pelanggaran nilai etika biasanya akan melibatkan bayak kerugian bagi orang lain, dan dengan demikian penggunaanya dilarang sama sekali. oleh karena itu, Al-Qur'an secara jelas dan tegas menggariskan seperangkat sistem nilai dan moral untuk mengatur dan memperlancarkan lalu lintas ekonomi dan bisnis manusia. Ini artinya, bahwa Islam tidak ingin bisnis itu bebas berjalan sesuai dengan logika, aturan dan kodratnya sendiri. ${ }^{4}$

Dalam dunia perdagangan, Islam menganjurkan agar nilai etika dijunjung tinggi dalam kehidupan. ${ }^{5}$ Dalam pandangan Islam seluruh segi manusia di dasarkan atas motif moral, seluruh segi hidup harus dikembalikan kepada fitrah penciptaan manusia yakni pengabdian kepada tuhan.

Pemasaran dapat disebut sebagai sebuah upaya marketer (pemasar) menata-mengelolah pasar untuk memenuhi permintaan konsumen dalam memuaskan kebutuhan atau keinginannya terhadap produk melalui pertukaran dan transaksi nilai dengan biaya antara pembeli dengan merketer. Proses pertukaran itu bukan yang gampang, marketer harus mencari pembeli, mengenali kebutuhan mereka, merancang produk dengan baik, menetapkan harga, mempromosikan

2 Sri Neni Imaniati, Hukum Ekonomi Dan Ekonomi Islam(Bandung: Mandarmaju,2002),h.161.

3 Yusuf Qardhawi, Peran Nilai Dan Moral Dalam Perekonomian Islam(Jakarta:Robbbani Press,2001), h.321

${ }^{4}$ Faisal Badroen, Etika Bisnis Dalam Islam (Jakarta: Prenadamedia Group, 2006), h. 177

${ }^{5}$ Muslich, Etika Bisnis Islam (Yogyakarta: Ekonisia, 2004),h. 47 
dan menyimpan serta mengirimkannya kepada konsumen, ini memerlukan perencanaan dan evaluasi yang terus-menerus. ${ }^{6}$

Pemasaran sering diartikan dengan penjualan.Pengertian pemasaran sebenarnya lebih luas dan kegiatan penjualan.Bahkan sebaliknya, penjualan adalah sebagian dari kegiatan pemasaran.pemasaran tidak hanya meliputi kegiatan menjual barang dan jasa saja, tetapi mencakup beberapa kegiatan lain yang cukup kompleks seperti riset mengenai perilaku konsumen, riset mengenai potensi pasar, kegiatan untuk mengembangkan produk baru, dan kegiatan mendistribusikan dan mempromosikan barang yang dijual. ${ }^{7}$

Banyak perusahaan yang berusaha memenangkan persaingan dengan cara memanfaatkan peluang bisnis yang ada dan berusaha menerapakan strategi pemasaran yang tepat dalam rangka menguasai pasar. $^{8}$

Islam memberikan ruang gerak yang luas bagi umat Islam untuk melakukan aktifitas ekonominya sehingga dapat meningkatkan kesejahteraannya asalkan tidak melanggar hukum. Berbisnis merupakan aktivitas yang sangat dianjurkan dalam ajaran Islam.Sebagai firman Allah QS. An-Nisa. 29:

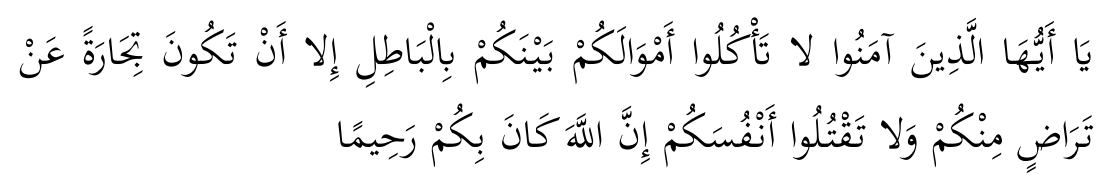

Wahai orang-orang yang beriman! janganlah kamu saling memakan harta sesamamu dengan jalan yang batil (tidak benar), kecuali dalam perdagangan yang berlaku atas dasar suka sama suka di antara kamu. Dan janganlah kamu membunuh dirimu. Sungguh, Allah maha penyayang kepadamu. ${ }^{9}$

Jual beli menurut etimologi atau bahasa diartikan sebagai pertukaran sesuatu dengan sesuatu (yang lain). Sedangkan menurut terminologi atau istilah yang dimaksud dengan jual beli adalah suatu perjanjian tukar-menukar benda atau barang yang mempunyai nilai

${ }^{6}$ Ali hasan,Manajemen Binis Syari'ah...,h.159

${ }^{7}$ Idri, Hadis Ekonomi Ekonomi Dalam Perspektif Hadis Nabi (Jakarta: Prenadamedia Group, 2015), h. 263

${ }^{8}$ Sutisna, Pelaku Konsumen \& Komunikasi Pemasaran, (Bandung: Remaja Rosdakarya, 2003), h. 15

${ }^{9}$ Departemen Agama, Al-Qur'an Dan Terjemahan, (Bandung:Diponegoro, 2008), h.83 
secara sukarela di antara kedua belah pihak, yang satu menerima bendabenda dan pihak lain menerimanya sesuai dengan perjanjian atau ketentuan yang telah dibenarkan syara'dan disepakati. ${ }^{10}$ Dengan demikian secara umum jual beli itu memang dihalalkan oleh Allah SWT dengan ketentuan apabila jual beli itu telah memenuhi syarat dan rukunnya.

SophieParis merupakan sebuah perusahaan yang didirikan oleh Bruno Hasson pada tahun 1995 dengan kantor pusatnya terletak di Jakarta. Perusahaan tersebut menyediakan berbagai produk fashion seperti tas, baju, aksesoris dan juga berbagai produk kosmetik. Produkproduk yang ditawarkan tersebut dikenal dengan merek sophie Martin. ${ }^{11}$

Brand "sophie Martin" diambil dari nama seorang desigher wanita berkebangsaan prancisyang telah merancang berbagai bentuk tas wanita yang trendy. Hingga kini produk-produk Sophie Paris telah merabah keluar negeri, antara lain: philipina, maroko, dan Vietnam. Dengan mengandalkan strategi pemasaran berbasis Multilevel Marketing (MLM), perusahaan berbasis Martin sukses membangun jaringan bisnis penjualan produk-produk fashionnya di Indonesia dan beberapa Negara di dunia. ${ }^{12}$

Kartu anggota (member card) dalam transaksi jual beli merupakan salah satu yang memiliki banyak problematika jika dikaitkan dengan ekonomi Islam. Para ulama kontemporer sepakat bahwa boleh hukumnya menerbitkan serta menggunakan member card yang diberikan secara cuma-cuma kepada para pelanggan. Seperti member card yang diterbitkan oleh beberapa maskapai penerbangan, dimana pemegangnya berhak mendapat berbagai fasilitas, misalnya, potongan harga tiket.

Keterangan ini merupakan keputusan Majma' Al-Fiqh Al-Islami (divisi fikih OKI), No. 127 (1/14) tahun 2003, yang berbunyi,"Kartu diskon yang diterbitkan oleh hotel, maskapai penerbangan dan beberapa perusahaan yang memberikan fasilitas yang mubah bagi pemegang kartu yang telah memenuhi poin tertentu, hukumnya boleh jika kartu diberikan secara cuma-cuma“.

Hal ini dibolehkan, karena akad yang terjadi antara penerbit kartu dan pemegang kartu adalah akad hibah, sehingga sekalipun asas kerja member card mengandung unsur gharar disebabkan ketidak-jelasan potongan harga barang yang didapatkan dan berapa besarnya potongan

\footnotetext{
${ }^{10}$ Hendi Suhendi, Fiqh Muamalah, (Jakarta:PT Rajawali Pers, 2008). h. 5

${ }^{11}$ Sophie Paris. www.sophieparis.com/id/index.php/m-about-us. Diakses Pada Tanggal 14 April 2016

12 Sophie Paris.www.sophieparis.com/id/index.php/m-about-us. Diakses Pada Tanggal 14 April 2016
} 
saat menerima member card, tidak mempengaruhi keabsahan akad. Sebagaimana yang telah dijelaskan.

Adapun member card yang pemegangnya disyaratkan membayar iuran keanggotaan atau membeli ID cardtersebut, maka terdapat perbedaan pendapat para ulama kontemporer. Salah satunya menurut pendapat Sami As Suwaylim hukumnya dibolehkan. Karena uang iuran tersebut adalah sebagai imbalan untuk pihak pengelola/penerbit kartu atas jasa mencari potongan harga dari perusahaan yang menjual barang/jasa serta kemudian memberitahukannya kepada pemegang member card. Dan upah atas kerja ini hukumnya halal.

Pendapat ini tidak kuat, karena jasa yang diberikan oleh penerbit kartu mengandung unsur gharar (ketidak jelasan). Bentuk ghararnya adalah pemegang kartu saat membayar iuran keanggotaan/membeli member card, tidak tahu berapa potongan harga yang akan dia dapatkan dan dari barang apa saja. Di samping itu, pemegang kartu juga tidak tahu apakah uang yang ia bayarkan lebih besar dari pada potongan harga yang ia dapatkan saat berbelanja. Jika uang yang ia bayarkan lebih besar dari potongan harga, berarti dia rugiDan sebaliknya. Ini jelas termasuk gharar (ketidak jelasan) dan qimar (perjudian).

Selain gharar, member card jenis ini juga mengandung unsur riba ba’i (riba jual beli), di mana pemegang kartu menukar uang iuran keanggotaan dengan uang potongan harga barang/jasa yang sejenis namun berbeda nominalnya dan tidak tunai. ${ }^{13}$

Disiniliah ada keracuan mengenai hukum member card yang sebenarnya.karena banyak perbedaan pendapat dari tokoh-tokoh agama mengenai hukum menggunakan member card dan dikaitkan dengan perspektif ekonomi Islam yang menjadikan tolak ukur problrmatika kontemporer tersebut.

Dalam hal ini penulis memilihSophie Paris sebagai obyek penelitian, dengan alasan bahwa ditinjau dari ekonomi Islam ada kalangan ulama kontemporer yang membolehkan dan ada kalangan yang melarang menggunakan member card, Sophie Paris adalah salah satu dari sekian banyak bisnis retail di kota Bengkulu, yang dalam praktek bisnisnya menggunakan sistem member cardatau keanggotaan bagi siapa saja yang menghendaki harga lebih murah dari harga eceran.Salah satu perbedaan dalam praktek penggunaan member card dengan bisnis retail lainnya, yaitu tujuan utama dari member cardSophie Paris ini tidak hanya untuk mendapatkan potongan harga melainkan juga untuk mengikuti program "kumpul-kumpul poin". Untuk mendapatkan kartu member

${ }^{13}$ Erwandi Tarmizi, Harta Haram Muamalat Kontemporer (Bogor: P.T. Berkat Mulia Insani, 2013), h. 309 
tersebut, akan dikenai biaya Rp.70.000.00,-.Setiap anggota yang menggunakan member card ini akan mendapatkan potongan harga sebesar 30\% untuk katalog Sophie Paris dan 20\% untuk katalog sundaydalam setiap produk yang dibeli.Jika anggota menggunakan kartu tersebut secara terus menerus, mungkin dia akan beruntung, tetapi sebaliknya jika dia tidak memakainya kecuali hanya sedikit saja, atautidak memakainya sama sekali, tentunya dia akan merugi. Ini adalah bentuk perjudian yang diharamkan Islamdalam pemberlakukan member card. Di Sophie Paris ini konsumen membeli produk dengan melihat gambar di katalog dengan harga yang sudah di tetapkan oleh produk tersebut.

Selain itu, pemegang kartu member Sophie Paris juga mendapat undian berhadiah. Melihat fenomena itulah penulis memandang apakah program-program dan undian yang diberlakukan dengan menggunakan member card sudah sesuai dengan Ekonomi Islam.

Pentingnya ekonomi Islam diterapkan dalam memecahkan masalah ini, dan itu membutuhkan penggalian dan pencarian dari hukum Islam yang berkenaan dengan ekonomi Islam ini, dan penulis yakin dalam hukum Islam masih banyak etika bisnis yang bisa diambil dan diterapkan dalam peraturan bisnis modern, sehingga tidak ada lagi keraguan bagi umat Islam dalam menjalankan usaha bisnis.

\section{Rumusan Masalah}

Berdasarkan latar belakang diatas, maka rumusan masalah dalam penelitian ini adalah sebagai berikut:

1. Bagaimana sistem member card dalam transaksi jual beli di Sophie Paris Hibrida Kota Bengkulu?

2. Bagaimana transaki jual beli dengan sistem member card dalam perspektif Ekonomi Islam?

\section{Tujuan Penelitian}

Adapun tujuan dilakukannya penelitian ini, sesuai dengan rumusan masalah di atas adalah :

1. Untuk mengetahui sistem member carddalam transaksi jual beli di Sophie Paris Hibrida Kota Bengkulu.

2. Untuk mengetahui transaki jual beli dengan sistem member card dalam perspektif Ekonomi Islam. 


\section{Hasil dan Pembahasan}

Sistem member card dalam transaksi jual beli di Sophie Paris merupakan hal yang dilakukan perusahaan dalam memasarkan produknya untuk mmenarik para konsumen bergabung menjadi anggota member. Bagi konsumen yang ingin mendaftarkan dirinya menjadi anggota maka ia akan mendapatkan potongan harga.

Berdasarkan penjelasan dari Yenni selaku pemilik Busisness Centre, Bagi para anggota yang sudah bergabung menjadi member akan diberikan fasilitas oleh Sophie Paris Hibrida berupa diskon harga, bonus, reward apabila pembelian produk meningkat. Promosi yang dilakukan untuk meningkatkan pemasaran Sophie Paris yaitu dengan menggunakan sistem online dan katalog yang terbit setiap bulan. Sistem Member Card sangat erat kaitannya dalam peningkatan Sophie Paris, dalam hal ini target yang ingin dicapai demi kemajuan Sophie Paris yaitu dengan merekrut member baru dan penjualan yang lebih meningkat. Dengan menggunakan sistem member card ini penjualan Sophie Paris akan mendapatkan keuntungan yang besar dalam penjualan produknya, hal ini dapat dilihat drai banyaknya orderan yang dipesan para member. Selain itu dengan sistem ini dapat memberikan banyak keuntungan pada para anggota member yang sudah bergabung.

Berdasarkan hasil dari penelitian ini sistem member cardDalam Transaksi Jual beli menurut Business centre dan asisten Business centrepertama, mendafatar sebagai member. Kedua, menyiapkan uang pendaftaran sebesar Rp.70.000,- berumur 17 tahun keatas, foto copy KTP dan foto copy No rekening. Ketiga, mengisi formulir pendaftaran. Keempat, setelah mendaftar Para anggota yang sudah bergabung menjadi member akan mendapatkan buku paduan member, ID member card, dan tas member. Kelima, ketika para member belanja akan mendapatkan diskon 30\% produk Sophie Paris dan 20\% produk Sunday. keenam, semakin banyak anggota member belanja atau semakin banyak poin yang terkumpul dalam pembelian produk sophie maka akan mendapatkan tambahan bonus dan reward setiap naik peringkat. Jika anggota member belanja pada bulan pertama senilai 1 juta dalam pembelian produk maka akan mendapatkan hadiah tas. Jika setiap bulan meningkat dalam pembelian produk maka akan mendapatkan bonus yang sesuai dengan peringkatnya. Dapat mengikuti training dan pelatihan pengembangan diri dengan berbagai tema.

Berdasarkan hasil dari penelitian para member adalah pelanggan yang sudah menjadi member lebih sering berbelanja dan sudah banyak yang memanfaatkan fungsi dari member card serta mengetahui benar sistem member card yang diberlakukan.Para anngota member disini banyak yang setuju dengan adanya sistem member card karena 
mendapatkan diskon dari harga yang telah normal.Tanggapan tentang promo-promo yang diadakan ada yang mengatakan bagus, ada yang mengatakan sedikit sekali barang yang tersedia untuk barang promo. Adapun promo yang disukai para member adalah baju, make up, dompet, tas, terkadang barang promo ini juga banyak tidak ada barangnya kecuali ada baju dan make up. Produk yang dipromosikan ini sudah sesuai dengan kenyataan harga maupun diskonnya. Jenis yang sering di beli para member ini adalah tas, dompet, make up, baju, aksesoris, perabot rumah tangga dengan alasannya karena kualitasnya bagus. Pelayanan yang diberikan sophie paris ini sudah sangat memuaskan bagi para member sophie paris hibrida. Keuntungan yang didapatkan para member saat berbelanja di sophie paris ini mendapatkan diskon dan mendapatkan bonus per bulan jika belanja di atas 5 juta. Kerugiannya barang sering kali kosong, padahal barang sudah lama dipesan dan barang tidak sesuai dengan pesanan.

Permasalahan barang yang dipesan tidak sesuai dengan pesanan, bisa dilakukan dengan cara penukaran apabila memastikan barang yang ditukar masih layak/baru, kemudian menghubungi Business Centre untuk proses ke kantor pusat Sophie Paris. Akan tetapi prakteknya mereka mempersulit prosedur pengembalian dan penukaran dengan berbagai alasan salah satunya harus disertai kartu star club sebagai syarat pengembalian dan penukaran produk tersebut.Menurut penulis mekanisme pengembalian ini sesuai apabila pihak member sebagai konsumen ridho menerima aturan dari Sophie Paris.

Praktek jual beli merupakan bagian dari ta'awun (saling menolong).Bagi pembeli menolong penjual yang membutuhkan uang (keuntungan), sedangkan bagi penjual juga berarti menolong pembeli yang membutuhkan barang.Karenanya, jual beli itu merupakan perbuatan yang mulia dan pelakunya mendapatkan keridhaan Allah SWT. Bahkan Rasulullah saw, menegaskan bahwa penjual yang jujur dan benar kelak diakhirat akan ditempatkan kelak bersama nabi, syuhada, dan orang-orang saleh. Hal ini menunjukkan tingginya derajat penjual yang jujur dan benar.

Lain halnya, jika jual beli mengandung unsur kezhaliman, seperti berdusta, mengurangi takaran, timbangan dan ukuran, maka tidak lagi bernilai ibadah tetapi sebaliknya, yaitu perbuatan dosa.Untuk menjadi pedagang yang jujur itu sangat berat, tetapi harus disadari bahwa kecurangan, kicuhan, dan kebohongan itu tidak ada gunanya.Untuk semantara jual beli seperti ini menguntungkan, tetapi justru sebaliknya, sangat merugikan.Untuk melakukan transaksi jual beli diperlukan saling percaya dan kerelaan. 
Islam mengajarkan kita untuk hidup bersosial antara sesama dalam memenuhi kebutuhan hidupnya. Salah satu cara bersosial yaitu dengan cara melakukan transaksi jula beli. Jual beli merupakan transaksi yang umum digunakan oleh masyarakat karena dalam setiap pemenuhan kebutuhan masyarakat tidak bisa berpaling untuk meninggalkan transaksi yang dilakukan antara pihak penjual yang mempunyai barang dan jasa serta pihak pembeli yang membutuhkan barang dan jasa. ${ }^{14}$

Member card merupakan hal yang baru dalam transaksi jual beli. Salah satunya Sophie Paris Hibrida kota Bengkulu sebagai pihak penyelenggara atau perantara antara penjual dan pembeli. Namun ini hanya salah satu bentuk lain dari potongan harga (diskon). Menurut fikih sebenarnya boleh atau sah-sah saja sistem dengan menggunakan member card, asalkan memang bentuk transaksi masih sesuai dengan prinsip-prinsip muamalah.

Terdapat lima prinsip dalam melaksanakan kegiatan muamalah yaitu tabadul al-manafi (memberikan keuntungan dan manfaat bersama), pemerataan, 'an taradhin (suka sama suka), 'adamul ghurur (tidak boleh terdapat tipu daya), kebaikan dan takwa, dan musyawarah (kerjasama). ${ }^{15}$

Sedangkan dalam hukum ekonomi syariah terdapat beberapa prinsip yang harus diperhatikan, karena prinsip-prinsip ini merupakan salah satu subtansi dari aktifitas ekonomi yang dianjurkan oleh syariah.

\section{- Prinsip-prinsip hukum Ekonomi Syariah:}

1. Pada asalnya hukum segala jenis muamalah adalah boleh. Tidak ada satu model/jenis muamalah pun yang tidak diperbolehkan, kecuali jika didapati adanya nash shahih yang melarangnya, atau model/jenis muamalah itu bertentangan deng prinsip muamalah Islam. Dasarnya adalah firman Allah, QS.Yunus : 59 ;

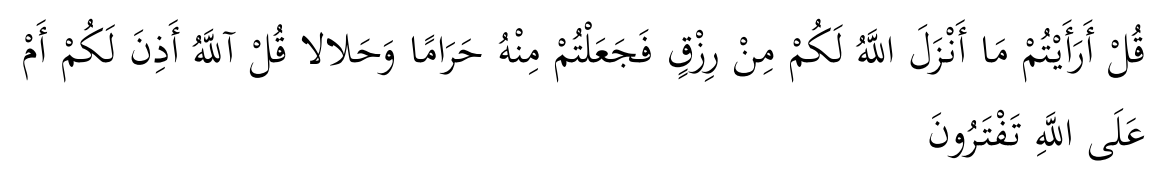

Katakanlah: "Terangkanlah kepadaku tentang rezki yang diturunkan Allah kepadamu, lalu kamu jadikan sebagiannya Haram dan

${ }^{14}$ Lukman Hakim, Prinsip-Prinsip Ekonomi Islam, Cetakan ke-1, (Yogyakarta: Graham Ilmu, 2012), h. 1

${ }^{15}$ Ma'ruf Amin, Fatwa Dalam Sistem Hukum Islam, Cet-I (Jakarta: A1sas Jakarta, 2008), h. 293 
(sebagiannya) halal". Katakanlah: "Apakah Allah Telah memberikan izin kepadamu (tentang ini) atau kamu mengada-adakan saja terhadap Allah ?"16

Dalam hal ini sistem member card dalam transaksi jual beli berarti boleh-boleh saja, karena tidak ada dalil Al-Qur'an maupun Hadits yang menentukan larangannya.

2. Ekonomi syariah dilakukan atas dasar sukarela (taradhi) tanpa mengandung unsur paksaan (ikrah).Prinsip sukarela ini merupakan prinsip yang fundamental dalam setiap aktifitas perekonomian syariah. ${ }^{17}$ Dalam hal in sistem member card Sophie Paris, sudah melakukan pandaftaran, membayar uang pendaftaran, mengetahui produk Sophie Paris mandapatkan diskon dan kedua belah pihak sudah saling merelakan dalam transaksi jual beli.

3. Terciptanya palayanan sosial (tahqiq al-khidmah al-ijtima'iyah) aktifitas ekonomi syariah harus diorientasikan pada terciptanya pelayanan sosial yang bisa meringankan beban kaum yang lemah secara ekonomi.Prinsip ini menjadi tujuan dari setiap aktifitas ekonomi syariah, karena dalam ekonomi syariah selain diperbolehkan untuk menambah keuntungan dan kekayaan yang berlimpah, juga harus memperhatikan kondisi sosial disekitarnya.

4. Terciptanya keadilan dan keseimbangan (al-'adlu wa attawazun).Muamalat dilaksanakan dengan memelihara nilai keadilan dan menghindari unsur-unsur kezaliman.Segala bentuk muamalat yang mengandung unsur penindasan tidak benar. Keadilan adalah salah satu sifat tuhan dan alquran menekankan agar manusia menjadikan sebagai ideal moral sebagai firman Allah SWT:

Sesungguhnya Allah menyuruh (kamu) berlaku adil dan berbuat kebajikan.

5. Tidak ada tipu daya ('adam al-gharar).Salah satunya prinsip lainnya itu adalah tidak adanya gharar dalam transaksinya.Al-iman alkhithabi menyatakan bahwa setiap jual beli yang tidak diketahui maksudnya dan tidak bisa diukur maka itu gharar.

6. Rofitable (al-istirbah).Setiap kegiatan ekonomi tentunya yang diharapkan adalah keuntungan.Tidak logis jika transaksi ekonomi tidak mengharapkan keuntungan. Tidak ada aturan dalam syariah

\footnotetext{
${ }^{16}$ Departemen Agama, Alquran Terjemahan, Yunus..., h. 59

${ }^{17}$ Ma'ruf Amin, Fatwa Dalam Sistem Hukum Islam, Cet-I..., h. 293
} 
yang melarang mengambil keuntungan dalam aktifitas perekonomian.Sebaliknya, syariah menganjurkan berniaga yang menguntungkan, sehingga bisa membayar zakat dan shadaqah. ${ }^{18}$

7. Muamalat dilakukan atas dasar pertimbangan mendatangkan manfaat dan menghindarkan mudharat (jalb al-mashalih wa dar'u al-mafasid) konsekuensi dari prinsip ini adalah bahwa segala bentuk muamalat yang dapat merusak atau mengganggu kehidupan masyarakat tidak dibenarkan, seperti perjudian, penjualan narkotika secara tidak sah, prostitusi dan sebagainya.

Jual beli dengan sistem member card di Sophie Paris Hibrida kota Bengkulu jelas memberikan manfaat kepada pelanggannya, dibandingkan mereka yang tidak menggunakan member card mereka akan mendapatkan bonus diskon potongan harga dari produk atau jasa tertentu dari harga normal tidak menggunakan member card tersebut.

Pada umumnya orang memerlukan benda yang ada pada orang lain (pemiliknya) dapat dimilki dengan mudah, tetapi pemiliknya kadangkadang tidak mau memberikannya. Adanya syariat jual beli menjadi wasilah (jalan) untuk mendapatkan keinginan tersebut, tanpa berbuat salah. Dalam melakukan aktifitas jual beli, seseorang tidak bisa bermuamalah secara sendirian, bila ia menjadi penjual, maka sudah jelas ia memerlukan pembeli, dan seterusnya.

Jual beli beli merupakan proses perpindahan kepemilikan yang didalam Islam diperbolehkan dan dihalalkan oleh Allah SWT. Sebagaimana dalam QS. Al-Baqarah 275, berbunyi:

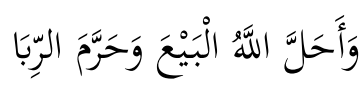

"Padahal Allah Telah menghalalkan jual beli dan mengharamkan riba"19

Dengan diperbolehkannya jual beli, maka manusia dapat memperoleh apa yang diiginkan sesuai dengan ketentuan-ketentuan yang telah diatur dalam Al-Qur'an. Sedangkan hikmah diperbolehkan jual beli dalam Islam untuk menghindari manusia dari kesulitan dalam bermuamalah dengan hartanya. Seseorang memiliki harta ditangannya

\footnotetext{
${ }^{18}$ Ma'ruf Amin, Fatwa Dalam Sistem Hukum Islam..., h. 306

${ }^{19}$ Departemen Agama, Al-Qur'an Dan Terjemahan..., h. 47
} 
namun dia tidak memerlukannya, sebaliknya dia memerlukan harta, namun harta yang diperlukannya itu ada ditangan orang lain. Kalau seandainya orang lain yang memiliki harta yang diinginkan itu juga memerlukan harta namun harta yang ada ditangannya yang tidak diperlukannya itu, maka dapat berlaku usaha tukar menukar yang dalam istilah dalam bahasa arab disebut al-bai'/jual beli. ${ }^{20}$ Dengan adanya aturan-aturan tersebut diharapkan mampu menciptakan keadilan dalam transaksi jual beli yang terjadi di masyarakat.

Islam telah mengajarkan bahwa segala perbuatan yang berhubungan sesama manusiaharus berlandaskan pada akad dan manfaat terhadap sesamanya dan juga bahwa setiap perbuatan yang merugikan pihak lain itu dilarang terutama dalam barang dang jasa. Karena Allah SWT telah mengisyaratkan bahwa transaksi ekonomi dalam rangka memenuhi kebutuhan manusia harus dengan cara yang baik dan benar, yaitu harus saling merelakan dan cara-cara yang bathil dilarang oleh agama.

Sehubungan dengan hal tersebut, Allah SW'T, berfirman dalam QS. An-Nisa: 29:

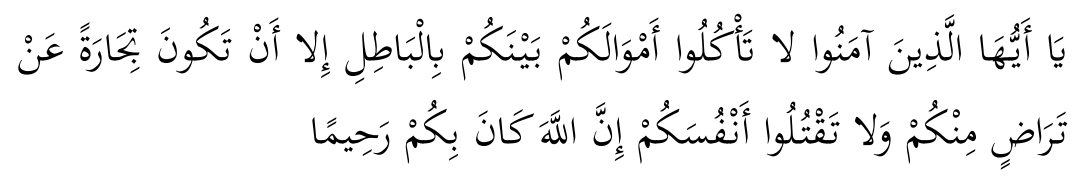

Hai orang-orang yang beriman, janganlah kamu saling memakan harta sesamamu dengan jalan yang batil, kecuali dengan jalan perniagaan yang berlaku dengan suka sama-suka di antara kamu. dan janganlah kamu membunuh dirimu. Sesungguhnya Allah adalah Maha Penyayang kepadamu. ${ }^{21}$

Ayat tersebut memberikan isyarat, bahwa perniagaan yang diperbolehkan dalam muamalah yang Islami adalah perniagaan yang dapat memperoleh keuntungan disamping juga bisa menimbulkan kerugian, tidak dapat disebut perdagangan, sehingga tidak diperbolehkanmelakukan riba.Pada dasarnya, setiap tindakan untuk mengembangkan harta kekayaan itu diperbolehkannya perniagaan asalkan saling rela. Sekalipun Al-Qur'an menyerukan ta'awun (pertolongan semata-mata mencari ridha Allah), dalam batasan tertentu 2003), h. 194

${ }^{20}$ Amir Syarifuddin, Garis-Geris Besar Fiqh, Cet I (Bogor: Kencana,

${ }^{21}$ Departemen Agama, Al-Qur'an Dan Terjemahan..., h. 83 
Al-Qur'an menghalalkan tijarah (niaga) yang bertujuan mencari keuntungan berdasarkan prinsip antaradhin (saling rela). ${ }^{22}$

Sistem Member card dalam transaksi jual beli merupakan salah satu yang memiliki problematika jika di kaitkan dengan ekonomi Islam. Adapun lembaga-lembaga fiqih internasional telah mengeluarkan fatwa mengaharamkan member card jika pemegang kartu ditarik membayar iuran uang jasa maka hukum kartu tidak boleh karena mengandung gharar. Adapun jika kartu yang diterbitkan oleh hotel, maskapai penerbangan dan beberapa perusahaan yang memberikan fasilitas yang mubah bagi pemegang kartu yang telah memenuhi poin-poin tertentu, hukumnya boleh jika kartu diberikan secara cuma-cuma kepada para pelanggan. Jadi disini terdapat perbedaan tentang adanya member card.

Sistem member card untuk mendapatkan potongan harga yang diberikan secara cuma-cuma itu tidak dipermasalahkan, hukumnya sah dan boleh-boleh saja. Namun bagaimana dengan member card yang berbayar sewaktu mendaftar menjadi anggota seperti di Sophie Paris hibrida kota Bengkulu. Jika dilihat dari keuntungan berlangganan member card sangat besar dibandingkan dengan tidak menggunakan sistem member card. Dengan membayar Rp.70.000,- di awal pendaftaran menjadi member bisa digunakan untuk mendapatkan potongan harga dari harga normal produk yang di sediakan di Sophie Paris pada katalognya serta program kumpul-kumpul poin. Dan yang terpenting dari akad jual beli ini adalah kedua belah pihak saling ridha. Format dari saling ridha adalah ijab dan qabul. Sedangkan subtansinya adalah "saling menguntungkan. Gharar (curang) atau tipuan, memeras dan paksaan merupakan cara-cara bertijarah secara bathil.

Melihat indikasi-indikasi tersebut, menurut penulis bahwa sistem member card dalam transaksi jual beli menurut ekonomi Islam baik yang diberikan secara cuma-cuma ataupun berbayar pada awal pendaftaran itu sah dan boleh saja, jika tidak bertentangan dengan prinsip ekonomi Syariah.Sistem member card di Sophie Paris Hibrida dengan sistem berbayar pada awal pandaftaran itu di haramkan atau tidak boleh karena uang pendaftaran atau administrasi bukan sebagai pengganti pembiayaan pembuatan member card melainkan uang pendaftaran jika ingin bergabung menjadi anggota member. Program kumpul-kumpul poin yang di adakan dengan menggunakan member card, dimana kedua belah pihak ini saling menguntungkan dan tidak ada merasa yang dirugikan itu boleh.Namun, mengenai pemesanan barang oleh anggota member card yang tidak sesuai harus diberikan kemudahan dalam proses penukaran,

${ }^{22}$ Muhamad Zahrah, Ushul Fiqh, Penerj: Saefullah Mas'shum Dkk, Cet Xiv (Jakarta: Pustaka Firdaus, 2011), h. 129-131 
karena berpengaruh terhadap etika bisnis dan jika tidak diberikan sesuai pesanan maka termasuk kategori penipuan.

Dari penjelasan lembaga-lembaga fatwa dapat dipahami bahwa pemegang member card di haruskan membayar iuran keanggotaan atau uang administrasi tidak dibolehkan. Tetapi, jika uang yang ditarik dari pemegang member card hanya sebatas uang pengganti biaya pembuatan member cardyang nyata-nyata dibutuhkan untuk menerbit kartu dan pihak penerbit sama sekali tidak mengambil keuntungan dari penerbit member card tersebut, baik jasa perantara ataupun namanya maka hal ini dapat disamakan dengan penerbitan kartu secara gratis.

\section{Penutup}

Dari hasil penelitian dan pembahasan di simpulkan bahwa: Sistem member card dalam transaksi jual beli di Sophie Paris Hibrida Kota Bengkulu meliputi hal sebagai berikut membayar uang pendaftaran Rp.70.000,-. mendapatkan diskon 30\% produk Sophie Paris dan 20\% produk Sunday. Member card berlaku seumur hidup bebas biaya bulanan/tahunan, berkesempatan mendapatkan penghasilan bulanan apabila member dalam pembelian/ penjualan meningkat, tambahan bonus dan reward setiap naik peringkat, berkesempatan mendapatkan berbagai hadiah dan bonus menarik, berkesempatan wisata keluar negeri.

Segala bentuk muamalah itu boleh. Sistem member card dalam transaksi jual beli menurut ekonomi Islam baik yang diberikan secara cuma-cuma ataupun berbayar itu sah dan boleh saja, jika tidak bertentangan dengan prinsip ekonomi syariah. Dan dari penjelasan lembaga-lembaga fatwa dapat dipahami member card yang diharuskan pemegang kartu tidak dibolehkan membayar iuran keanggotaan atau uang administrasi. Tetapi, jika uang yang ditarik dari pemegang kartu hanya sebatas uang pengganti biaya pembuatan member card yang nyata-nyata dibutuhkan untuk menerbitkan kartu dan pihak penerbit sama sekali tidak mengambil keuntungan dari penerbitan tersebut, baik jasa perantara ataupun namanya maka hal ini dapat disamakan dengan penerbitan kartu secara gratis. Sistem member card di Sophie Paris Hibrida dengan sistem berbayar pada awal pandaftaran itu di haramkan atau tidak boleh karena uang pendaftaran atau administrasi bukan sebagai pengganti pembiayaan pembuatan member card melainkan uang pendaftaran jika ingin bergabung menjadi anggota member. 


\section{Daftar Pustaka}

Al-'Asqolani, Ibnu Hajar. Bulughul Maram Min Adillati Ahkaam, Jokjakarta: Hikampustaka, 2013

Amin, Ma'ruf. Fatwa Dalam Sistem Hukum Islam.Cet-I. Jakarta: A isas Jakarta, 2008.

Aziz, Abdul, \& Mariyah Ulfah.Kapita Seleka Ekonomi Islam Kontemporer. Cirebon: ALFABETA. 2010.

Badroen, Faisal. Etika Bisnis Dalam Islam.Jakarta : Prenadamedia Group. 2006.

Dani, tan, Stevano.Pengaruh Kepuasan Pelanggan Membership Card Oriflamme Terhadap Loyalitas Pelanggan Pada Kosmetika Oriflame Di Yogyakarta. Universitas Kristen Satya Wacana, Skripsi Sarjana. Fakultas Ekonomika Dan Bisnis Program Studi Manajemen. 2012.

Departemen Agama, Al-Qur'an Dan Terjemahan. Bandung:Diponegoro, 2008.

Ebta Setiawan, KBBI Online. http://kbbi.web.id/sistem. Diakses Pada Tanggal 4April 2016

Fitrya, Erry, Primadhany,"Tinjauan Hukum Islam Terhadap Sistem Diskon (Studi Kasus Di Pertokoan Pasar Baru Palangkarya)" Universitas Islam Negeri Maulana Malik Ibrahim Malang, Karya Ilmiah, Jurusan Hukum Bisnis Syari'ah. 2012.

Ghazaly, Abdul Rahman, Ghufron Ihsan, Sapiudin Shidiq.fiqih Muamalat. Jakarta: Kencana. 2010

Hakim, Lukman.Prinsip-Prinsip Ekonomi Islam. Surakarta: Erlangga. 2012. 2000 .

Haroen, Nasrun. Fiqih Muamalah. Jakarta: Graya Media Pratama,

Hasan, Ali. Berbagai Macam Transaksi, Jakarta: PT. Raja Grafindo Persada, 2003. Cet-1.

Hasan, Ali. Manajemen Bisnis Syariah. Yogyakarta: Pustaka Pelajar. 2009

Huda ,Qomaratull. Fiqh Muamalah. Yogyakarta: Teras, 2011

Idri. Hadis Ekonomi Ekonomi Dalam Perspektif Hadis Nabi. Jakarta : Prenadamedia group. 2015. 
Imaniati, Sri Neni. Hukum Ekonomi Dan Ekonomi Islam,Bandung: Mandarmaju. 2002.

Mardani, Fiqih Ekonomi Syaria: Fiqih Muamalah . Jakarta: Kencana, 2012.

Mas'adi. Ghufran s, Fiqih Muamalah Kontekstual, cet I, Jakarta: Pt Rajagrafindo Persada, 2002.

Muslich. ETIKA BISNIS ISLAM Landasan Filosofis, Normatif Dan Subtansi Implementatif. Yogyakarta : Ekoonisia. 2004.

Najah, Ahmad Zain An. Hukum menggunakan member card.http://www.ahmadzain.com/read/karya-tulis//262/hukummenggunakan-member-card/.Diakses Pada Tanggal 02 April 2016

Narbuko.metode penelitian kualitatif.Jakarta: pustaka setia, 2003.

Oktaviani, Dwi. Pemberian Potongan Harga Dengan Kartu Member Dalam Transaksi Jual Beli Di Grosir Batik Yudhistira Yogyakarta Ditinjau Dari Hukum Islam Dan Undang-Undang Perilaku Konsumen, Universitas Islam Negeri Sunan Kalijaga Yogyakarta, Skripsi Sarjana, Fakultas Syari'ah dan Hukum. 2015.

Qardhawi, Yusuf.Peran Nilai Dan Moral Dalam Perekonomian Islam, Jakarta: Robbbani Press. 2001

Sekilas Sejarah Sophie Martin Paris, https://citra2408.wordpress.com/2012/10/13/helo-world. Diakses 14 April 2016

Serli, Wijaya. Implementasi Membership Card Dan Pengaruhnya Dalam Meningkatkan Loyalitas Pengunjung Restoran Di Surabaya.Universitas Kristen Petra: Skripsi Sarjana, Program Studi Manajemen Perhotelan .2011.

Sophie Paris. www.sophieparis.com/id/index.php/m-about-us. Diakses Pada Tanggal 14 april 2016

Suhendi, Hendi.Fiqh Muamalah. Jakarta:PT Rajawali Pers. 2010.

Sutisna.Pelaku Konsumen \& Komunikasi Pemasaran. Bandung: Remaja Rosdakarya. 2003

Syafe'i, Rachmat.Fiqih Muamalah.Bandung: Pustaka Setia, 2001.

Syamhudi, Kholid, Tentang Kartu Member (Keanggotaan) dan Neraka, http://klikuk.com/f77FS. Dikses Pada Tanggal 17 april 2016

Tanjung, Hendri dan Abrista Devi.Metode Penelitian Ekonomi Islam.Jakarta: Gramata Publishing. 2013 
50 | Manhaj: Jurnal Penelitian dan Pengabdian Masyarakat | Vol. 4 No. 1, 2019

Tarmizi., Erwandi. Harta Haram Muamalat Kontemporer. Bogor: P.T. Berkat Mulia Insani,2013

Zahrah, Muhammad. Ushul Fiqh, Penerj: Saefullah Mas'shum DKK, Cet XIV. Jakarta:pustaka Firdaus, 2011. 